THE LANGUAGES OF INDONESIAN POLITICS

The language of contemporary Indonesian politics has recently been the object of a certain amount of attention, usually rather cantankerous, from Gallic and American critics. While the French observers have tended to see mainly "réiterations obsessionelles" and "les cris sourds d'une civilisation mourante", our more programoriented analysts have concerned themselves with what they feel to be vague sloganeering and hypocritical propagandizing. In both cases, however, the forms of modern Indonesian, in so far as they are understood, are seen as forms of evasion and defeat before the challenges of the old West, and in the gloomy comments of both can be detected an unmistakeable Schadenfreude. No one has yet attempted to look at the language of contemporary Indonesia as an enterprise for the mastery of a gigantic cultural crisis, and a partly subconscious project for the assumption of "modernity" within the modalities of an autonomous and autochthonous socialpolitical tradition. Yet this is of decisive importance for the generations that lie ahead, since with every decade that passes, "Indonesian" is becoming more and more the one language through which Indonesians of all kinds are coming to grips with modern and ancient realities. The polyglots of the colonial and early post-revolutionary period are slowly beginning to disappear from the scene. The "new Indonesian" is therefore of paramount importance for the shaping of the younger Indonesian national consciousness.

The extraordinary character of modern "political" Indonesian (with which we are especially concerned) is that it is inevitably the heir of three separate languages and two separate linguistic-cultural traditions. The languages are Dutch, Javanese, and "Revolutionary Malay" - the traditions are Dutch-Western and Javanese. The "enterprise" of modern Indonesian in the 60 s and $70 \mathrm{~s}$ is therefore the synthesis of a new political-cultural intelligence and perspective, which was completely fragmented in the colonial and early post-colonial period, and the restoration of a unity of consciousness such as has not existed for the Indonesian literati since the initial confrontation with Dutch colonialism. The new Indonesian has had to develop into a means of communication which can not only express Indonesian nationalism, but Indonesian aspirations, Indonesian traditions and "international realities" - within the limits of a single vocabulary. The colossal cultural effort involved, and the remarkable success achieved, seems to me to have been inadequately appreciated, and the morphology of the transformations involved insufficiently studied. 
Colonial Indonesia was a bureaucratic Wonderland: a cluster of interacting but basically separate linguistic and cultural universes, linked by the miracle of modern bureaucratic and technical organization. Each language, be it Batak, Sundanese, Javanese or Dutch, was the product of separate historical experiences, community organizations, literary and cultural specialization and metaphysical outlook. The discontinuities between these linguistic-cultural universes were fundamental to the structure of colonialism. The response to these discontinuities on the part of "Indonesian" literati was inevitably therefore primarily and primordially expressed in bi-lingualism, since only through the mastery of the language of the other could the chasm between the universes be bridged and the colonial system challenged on something like even ground.

But the leap out of (say) Batak into Dutch meant far more than the acquisition of a new technical vocabulary and the ability to peer into the arcana of Dutch domination. It also involved the development of two inter-acting or conflicting modes of consciousness. The new generation of bi-lingual literati (which arose about the end of the 19th Century) thus became cultural "middlemen," but inevitably middlemen who were as much involved in the effort to control two mental universes as facilitating communication between them. In the colonial situation, bilingualism was not merely a technical, but also a grave psychological and ultimately religious, problem.

For the acquisition of the colonial language implied a change in the modalities of consciousness. It was far more than just the discovery of a radically different set of phonetic equivalents for the inventory of one's own language. The structure of Dutch (and through it of European) thought and consciousness was itself fundamentally different from those of the traditional Indonesian languages, and the advance to bi-lingualism therefore in itself created profound mental and spiritual displacement what our modern economic-cultural missionaries like to call "cultural shock," but at a much deeper and more human level. The profounder the knowledge of the acquired language, and the more this language substituted itself for the aboriginal language as the medium of thought and discourse, the more destructive and/or creative (according to individual talents and situations) became the two-mindedness of the literati.

It is one of the ironies of colonial history that, since the psychological effort to maintain equilibrium between two universes is so immense that few can sustain it, the "radicals" who leapt out into Dutch and "conquered" the organization and methodology of colonial society, found themselves increasingly isolated from the aboriginal Indonesian world, and having acted as pioneers they found themselves later for a large part culturally marooned on the farther western shore. A newer generation grew up for whom the "conquest" was a thing of the past, and whose basic task was 
the development of a counter-language to Dutch, a modern, nationalist language, which would re-establish the connection with Indonesian traditions in itself, without compelling each individual to master the crisis internally through a bi-lingual conquest. While one generation struggled to work its way out of the traditional modes of thinking, the next has been trying to reestablish contact with and build on them. In this attempt, an immense act of social and national creativity is involved.

The theoretical implications of this quest for a fundamental national unity (not basically a question of inter-regional homogenization but one of spiritual unity between mental universes) have too often been ignored, and reduced to superficial maintenance of "folk-culture" in a quite synthetic way. There has been too much focus on bureaucratic "marination" of the external emblems of aboriginal tradition (costumes, adat, etc.), and too little on the deeper communal quest for a sense of rooted identity, expressed at all levels of the population, through the adventures and transformations of the national language.

The main thrust of what follows below therefore is the search for the over-all lines of this act of creativity. The main focus will be on the Javanese, for a number of reasons, the most important of which is that the combination of political power, numbers and strength of cultural identity of the Javanese has made them the single most creative force in developing the new Indonesian. How has "Revolutionary Malay" set about the task of disciplining and uniting the bureaucratic colonial vocabulary, the Western democratic-socialist vocabulary, the nationalistrevolutionary vocabulary, and that of Javanese tradition? How has this "synthesis" been stretched or transformed to adjust to the "realities" of urban Indonesia today? I believe that the most satisfactory perspective for understanding this development is a growing imposition of Javanese "flesh" on the "skeleton" of "Revolutionary Malay" - though this is in fact only a part of an immensely complicated and perhaps ultimately incomprehensible process.

It may be helpful to start with some consideration of an earlier confrontation between the Javanese and an alien civilization - that of Middle Eastern Islam - since the pattern of modalities is quite clearly visible in that now-distant clash.

While secular power in 0ld Java was largely held by bureaucratic functionaries of the rulers, particularly the Bupati, religious and intellectual power was wielded, particularly in those areas where royal authority was weakest, by the kjai. One found them in the Pasisir, and in traditional "rebel" areas (remote valley-fortresses like Bagelen and Ponorogo). The kjai was essentially a man of greater knowledge and wisdom than his 
fellows, and accordingly the main institution of $\mathrm{kjai}$ was the pesantrèn or rural Islamic school. The pesantrèn education was quite explicitly an inwijding, an initiation into the higher wisdom. The social structure of the pesantrèn, in which the holy kjai himself was assisted by more or less advanced pupils, reflected the conception of education as a path to wisdom (rather than knowledge). Now the prestige of the kjai rested on many factors, on his reputed ancestry, his magical healing powers, his experience, and his personal character - but above all on his mastery of an esoteric vocabulary. The most important element in this vocabulary was, generally speaking, Arabic.

The normal method of instruction of boys and youths in the pesantrèn was the inculcation by rote of extensive passages of Arabic or Koranic texts - and their subsequent elucidation by the Master. It has often been claimed that this rote-learning of the Koran represents the decadence or fossilization of Islam in Java. Yet it seems much more comprehensible to see it as a most important and convincing sign of Java's defence against Arabic culture, and its final conquest of this alien infiltration. The "domestication" of Islam and Arabic by the Javanese cultural impulse was done through the transformation of the Koran into a hermetic text-book of riddles and paradoxes. Arabic was maintained as the language of "initiation" precisely because Arabic was not understood (vide the present disastrous attempts to make the Latin mass "comprehensible!")s the whole point of a spiritual ritual in an uncomprehended language is that it manifests power, limitless power, and implies a deliberately nonrational mode of cognition. Islam had forbidden the continued used of Shivaitic and Tantric mantra; Java answered by turning the Koran into a book of mantra.

(The fact that until quite recently it was forbidden to "translate" the Koran under Islamic law itself simply served to justify a "principle" which derived from the local culture.)

The pupils in the pesantrèn then acquired their Koranic texts by rote, and the excelling pupil. was the boy who could recite without mistakes. Since the youth clearly "understood" nothing of what he was saying, the importance attached to recital errors has clear "magical" overtones, recalling for example balian incantations in Central Kalimantan, where mistakes forebode trouble and difficulties for the community if they are not corrected.

The second step in a pesantrèn education was the "decoding" of the Koranic texts and of Javanese-language riddles and paradoxes. This part of the educational system is marvellously depicted in the pages of the Serat Tjentini, in which much of the action revolves around wandering santri (the original meaning is "pupil") travelling from one pesantren to another, testing each other's skill in unravelling puzzles and religious conundrums. 
The essential point of the conundrum is that it defies everyday reality by removing logic from the phenomenological to the linguistic plane. Asking the question: "When is a man not a man?" is phenomenologically nonsense. The resolution is linguistic: "When he is a lemon." The point thus turns on a pun in the word "lemon." In this case the pun is totally "culturally deprived." But the religious function of the pun is to bridge two levels of cognition, and to create a kind of linguistic-religious causality (compare for example, some of the poems of St. John of the Cross). Taking a specifically Javanese example, one of the best-known religious puns is made on the name of the wajang hero Judisțira's magical weapon, the Kalimas åda, which takes the form of a piece of esoteric writing, an incomprehensible document of great power. It is in fact not what is written in the Kalimasada that is important, but that certain syllables are inscribed on it in a certain order by a certain person at a certain time. While the Kalimásada is an authentic symbol of a pre-Islamic cultural tradition, it is common to find it referred to in Javanese Islamic circles: but now under the guise of the Kalimah Sahadat, the Koranic credo or confession of faith. (There is even a legend describing how Judistirà gave his weapon to Sunan Kalidjaga, one of the nine pioneering Islamic "apostles" in Java). One might then reverse our original riddle and ask: "When is the Kalimắsádá not the Kalimásädä?" Answer: "When it is the Kalimah Sahadat."

The pun is of great importance to the Javanese Islamic tradition since it represents a sort of "capsulated" formula of an intuition. Neither historical nor linguistic analysis has any real purchase on this intuition, because it is built into the miraculous quality of the pun itself (How can it be coincidental? Is the idea of coincidence meaningful only in certain cultures?), revealing another level of Being flowing in and out of the phenomena. (From an outsider, "reductivist" point-of-view of course the pun expresses the will-to-unity of the Javanese cultural tradition, the urge to unite or absorb conflicting cultural streans through language or linguistic symbolism.)

Thus the innerlijke wijsheid of the pesantrèn (and this is even truer of the more abangan religious thought of South Central Java) consists almost entirely of ascetic practices, rituals and the presentation and analysis of spells, conundrums and paradoxes (prenèsan). The common denominator is invariably: the phenomena are not always what they seem to be; what really is, may not appear to be so. One finds simple paradoxes such as the old tag: "Sing ànă, ora ana; sing ora ană, àna." (What is, is not; what is not, is.) More concretely the paradox is divined in the word longan, which literally means the space under a chair, table or bed. The riddles of being and non-being are fondly expressed in the conundrum that longan exists, yet does not exist. No chair can exist without it, yet it cannot exist without a chair. 
The third aspect of the pesantrèn education which should be noted, since it runs through much of contemporary Indonesian education including the Universities, is that education has an unmistakeable metaphysical dimension; it is part of a long process of spiritual and mental training, an initiation into something inaccessible to the outsider. Far from being "pragmatic" in the Deweyan sense, education is seen as the key to an otherwise locked door. This is also one way of interpreting the well-known "relativism" of the Javanese Weltanschauung. The characteristic linguistic paradoxes and polar juxtapositions of traditional Javanese education allow for considerable tolerance of ambiguity in the phenomena - far more at least than an American or Dutch education - and this is because the paradoxes are an expression of a certainty and a truth - a metaphysical intuition of the commonality of being. Thus the psychological strain of accepting paradox and ambiguity is small, since they are seen less as conflicting opposites than as inter-related complementarities. By contrast, in Atlantic societies, precisely because any real sense of "certainty" in this ultimate sense has long since vanished, if it ever existed, and because we are trained to think in terms of conflict rather than complementarity, overt paradox and manifest contradictions arouse anxiety and the sense of skating out to sea on fast-melting ice. An evident ontological certitude underlies the shifting relativism of Javanese philosophy. The phenomena do not have to be saved, since they are never the sum of what Is. The real and the really real are closely connected, but not identical, and therefore it never does to be too closely committed to either.

It should now be clear that the whole mode of old Javanese Islam is in sharp contrast to that of the Middle East. Since the rise of reformist Muhammadijah Islam in Java in the early years of this century however, which took Middle Eastern "Reform" Islam as its mocel, there has been a sharp break in the Islamic ummat on Java. The "Reform" elements in Masjumi, for example, have made so bold as to say that the Koran means what it says! With Talmudic literalism they have transformed the Koran from a key to a sort of religious highway Code, and denied the complementary dualism which is fundamental to traditional Javanese thinking. Hence the violent N.U. hostility to Masjumi.

Whereas for the "ideal" modernist Arabic is the language of religion, which therefore must be directly understood, the affective non-liturgical language of the pesantren traditionalists is Javanese. Partly this is because Javanese is the motherlanguage, with all the secret inflexions and resonances which no foreign language can ever convey, partly because for the Javanese their language is so strongly felt to be the major expression of their collectivity's identity. The allusive alliterativeness, the highly developed onomatopoeia of Javanese, and its rich, sensory vocabulary provide a treasury of non-causal causalities and interconnections and an enduring sense of a hidden continuity 
flowing in and around the phenomena, down to the most intimate sphere of people's lives. When the pesindèn at a wajang performance wishes to rest and warn the dalang to take over, she weaves the word ron ing mlindjo (leaves of the mlindjo tree) into her song. Since these leaves are also known as so and the Javankse word for rest is ngaso, the connection is at once felt, and to the mystification of the uninitiated, the dalang takes over the burden of the singing.

The Javanese sense of the inter-relatedness of the phenomena and yet scepticism about their ultimate reality is fundamental to any understanding of the Javanese political style. In Javanese social intercourse, great stress was traditionally laid on an emptiness between facial expression and mental attitude. Regardless of one's emotions, one's face should express "appropriate" feelings or complete impassivity. This sense of the face as a kind of built-in mask has been commented on by travellers and students of Javanese life. But it is generally misunderstood as: the real person is the "emotion," the false person is the "mask" or face. In fact it is not nearly as simple as that. In the mask-dance for example, the relationship of the dancer to his mask is highly ambiguous: the mask may "formally" express an emotion that the dancer feels but dare not express (the mask provides an alibi), or it may simply be "distracting," a disguise misleading the audience, or it may be magnetic (there is a common belief that women will fall madly in love with a masked man but not with the same man unmasked), or again it may take possession of him, so that the man becomes the mask. The relationship between the real and really real is thus once again obscure and intricate. It is difficult or impossible to say which is which. And when the dalang sits behind the screen, manipulating the puppets as he choóses, imitating their various voices, ideas, passions and personalities, he becomes at once all of them and none of them.

\section{The Pamongpradja}

Whereas the most asli type of Javanese authority, such as we have just considered, was mono-lingual, or at least bi-lingual only in a very special sense - that he had acquired a store of esoteric Arabic mantra - the elaboration of a colonial bureaucracy (the Binnenlands Bestuur) with largely secular powers, required the cultivation of bi-or even, later, tri-lingualism. Long before the rise of the modern nationalist intelligentsia, the Javanese literati, in their function as lower-level administrators of the colonial government, had started to face the challenge of Dutch rule by the slow acquisition of Dutch and Dutch-Western modes of thinking. The typical figures in this respect were the Bupati, particularly the Bupati in areas rather remote from Surakarta and Jogjakarta (Djepara, Rembang, Tuban, Banjumas, Banten are all good examples). Since the Bupati was par excellence the main nexus between the rural Javanese populace and the 
colonial government, and thus positionally the vital middleman between two mutually uncomprehending worlds, he was forced to cultivate the two-mindedness that we have mentioned very early on. Whereas vis-à-vis the Dutch his position was weak (in spite of Max Havelaar!) and clearly subordinate, vis-à-vis the Javanese population he remained the apex of the social order in a society intensely conscious of status hierarchies. While the Dutch did what they could (within the logic of the colonial system) to maintain the outward grandeur and pomp of the Bupati's position, it was clear to those concerned that this was pretty much a sandiwara; that the 'formal' apparatus of power was quite different from the 'real'; that for example the contrôleur, though below the Bupati in rank and dignity, nevertheless effectively ran the government. A similar development had after all long since been in evidence in the royal capitals, where, in spite of the immense formal majesty and prestige of the sunan and sultan, it was everywhere understood that effective power was in the hands of the Rijksbestuurder or Patih, a Dutch appointee. The relationship controleur-Bupati and Patih-Sunan were in many respects dissimilar, but in one critical respect they were alike in their disassociation of what our scholars call charismatic and administrative functions. In each case the magico-religious figure was powerless on a day-to-day level; yet his authority was essential for the smooth. cking of the system controlled by his opposite number. Once again one detects complementarities, and an ambiguous, symbiotic relationship, recalling the mask and its wearer, the dalang and his wajang.

Although from the colonial point of view the Bupati was basically an official or administrator, from the Javanese point of view he was first and foremost the most eminent prijaji in his area - and prijaji is perhaps best defined as the literate man. The prestige of literacy in a land where illiteracy ran to well over $90 \%$ of the population, is at once easy and impossible to comprehend. The written word assumes a character quite different to the literate and the illiterate man. For the one it is a means of communication; for the other a sign or symbol of an inaccessible world. The power of the Bupati was, at bottom, the power of literacy against illiteracy. In the language of the Javanese, the reflection of this "stratification" appeared, probably not earlier than the late 17th Century, in the structural differentiation between the two major levels of discourse, krama and ngoko. Krămă, par excellence the language of the prijaji, is a consciously archaizing Sanskritic sub-language, developed largely to emphasize and "build into" the larger Javanese language the increasing hierarchization of Javanese society under the influence of Dutch pressure and later control. While krama is essentially an honorifc language, and thus largely spoken up the social hierarchy, full mastery of the vocabulary requires a high initial degree of education. To this day social prestige among the Javanese is indicated most clearly by an individual's mastery of the finer forms of this langage de politesse. The rolling, melodious, polysyllabic krama forms serve to emphasize 
in themselves the measuredness, sense of distance and space between the ranks of Javanese society. Ngoko on the other hand is terse, acerbic, humorous and sensuous in a direct, almost physical way. It is spoken down the social hierarchy and among very close equals, friends or family. The duality of these two sublanguages however does not only reflect the stratifications of Javanese social structure but a dualism in the Javanese mind. Krámå is official, aspirative, and a little like a mask. Ngoko is private, cynical and/or humorous and a little like the heart. But neither can be fully appreciated without the other, and both "live" in their mutual complementarity.

In his relationships with the Javanese world then, the Bupati was bounded and conditioned by the structures of Javanese as a language. The values and orientations of that language persisted in his life since they had real application to what was still largely a traditional community. But in his relationship with his Dutch superiors and with his prijaji colleagues and equals in and outside the pamongpradja, who shared a Dutch education with him, the younger Bupati of the late nineteenth and early twentieth centuries 12 compelled to leave Javanese behind him. The acquisition of Dutch (and also Malay, though Malay had a special role of its own, not in the least comparable to Dutch), was necessary to an adequate performance of the increasingly technical-managerial aspect of his role, particularly with the introduction of the Ethical Policy around the turn of the Century, calling for a great expansion of governmental services both in the economic and social fields.

In the Indies world - as opposed to the purely Javanese Dutch came thus to assume some of the functions of krama, a high status language which denoted the degree of the individual's "literacy," and in which the operations, particularly of the government, were most honorifically expressed.(1) Whereas for the Dutch in Java the Dutch language remained, among themselves, a language without any particular nuances or prestige, it assumed a quite different place in the Weltanschauung of the younger Javanese pamongpradja. Precisely because Dutch educational policy, in contrast to British policy in India for example, was to limit the number of Dutch-speakers to what was strictly necessary for the purposes of the colonial regime, Dutch acquired an "esoteric" aura of being the language of the inner elite, which it has not lost to the present day. Moreover since Dutch education tended to be given to people of known lineage - people of "good family" naturally - by a reverse process, knowledge of Dutch was generally taken to indicate breeding and literati ancestry.

(1) One still often hears Dutch referred to jokingly as kråmå inggilnja Djakarta - the krama inggil of Djakarta. Kramå inggil is a specially high-status form of kråmă generally confined to the old royal court capitals. 
It rapidly became fashionable for the younger pamongpradja families to speak Dutch in their homes, often with a heavy Javanese accent and including many Javanese words. Particularly in the larger cities, among professional people, Dutch tended to be used also for those situations for which the older regional language seemed ill-adapted: for example, writing love-letters, discussing women's fashions, and the Western amusements and appliances available in the metropolis.

But it was in the offices of the colonial bureaucracy that the political effects of the new bi-lingualism were most immediately felt. From their Dutch superiors the younger Javanese officials divined a new vocabulary of politics, which they rapidly absorbed. For the conventional colonial official, the world divided normally into two: praters and werkers. Praters (talkers) were especially the politicians, parliamentarians, idealists, "reds" and ideologues. Werkers (doers) were busy and practical men of affairs, who kept their mouths shut, "ran a tight ship," had a strong sense of hierarchy and knew their place down to the last $e$. The division was in many ways a conventional pejorative distinction between administrators and politicians. Furthermore Dutch officialdom clearly defined their Great Society as consisting of Rust en Orde (Tranquillity and Order), which was constantly being threatened by "chaos," relletjes, opstanden, revolutionnaire uitbarstingen (in ascending order of seriousness). Any reading of Dutch colonial literature astounds one with its obsessive concern with a (supposedly fragile) orde. (2) Society (in all serious matters) was divided between law-givers and lawtakers, the regulators and the regulated. The politician was an intruder and an outsider, to be kept firmly in his place. The essential danger was always that the hierarchy would be disturbed( 3 ) by "lower" elements making claims to power in the name of communal, revolutionary and/or democratic forces. (4) The good political state is stabiel, the bad labiel.

(2) In those palmy days it was still orde, not yet tata-tertib and keamanan.

(3) Thus General Soeharto recently expressed his relief that with the suppression of the P.K.I. "the hierarchy - of the Revolution - would no longer be disturbed."

(4) One finds this as the basis of Alers' fascinating and much neglected study of modern Indonesian politics, Om een Rode of Groene Merdeka, where the basic conflict is drawn between the "green" and "red" forces. These colours do not represent Islam and Communism, but rather the forces of order-rule-hierarchy and those of revolution-spontaneity-comnunity. Alers' evident sneaking sympathy with the "reds" in no way takes away from the fact that the whole descriptive analysis is essentially the colonial administrators' political perspective stood on its head. These categories are neither sociologically nor economically rooted. They are much more projections of the Calvinist spirit, or the battle between Ego and Id. 
A curious osmosis or mutual acculturation took place between the Dutch and Javanese bureaucratic hierarchies, which can not be properly traced here, based on a certain communion of interests and outlooks (bureaucrats of the world unite?). In the 19th Century, the osmosis had mainly taken the form of Javanization of the Dutch, most frequently in bed or in the kitchen through the Dutch official's huishoudster or "native" mistress. Javanese regalia and paraphernalia (golden umbrellas, Javanese titles, etc.) were happily adopted by Dutch administrators. In the 20 th Century however, especially after the opening of the Suez Canal had permitted a massive immigration of Dutch women, this "Javanization" came to an end, signalized by the Van Heutsz Hormat Circular, which forever banned the use of Javanese ceremony and regalia by Dutch officials, and the rapid decline of the older type of inter-racial marriage. The osmosis then began to work the other way, with Javanese literati acquiring (mainly in Holland) Dutch wives, and the regalia of Dutch authority. (5)

The osmosis between Dutch and Javanese administrator was rendered all the easier in that certain aspects of Dutch and Javanese bureaucratic culture ran along surprisingly similar lines. The hostility of many of the older ambtenaren to the rising, thrusting capitalist class in the Indies, which often had the ear of The Hague, and which increasingly threatened the power-monopoly of the Binnenlands Bestuur, was not far (especially as the ambtenaren, in contact with the Javanese, often liked to assume aristocratic and pseudo-aristocratic airs) from the Javanese prijaji's disdain for dagang (trade). The Dutch obsession with detail, rule and rank, categorization and classification accorded well with the Javanese prijaji love of clear hierarchies and the naming of the phenomena. Especially with the rise of the Ethical generation of Dutch administrators, steeped in romantic ideas of adat and the need to protect the inlander

(5) Alers has an intriguing analysis of what he calls the Mokolo of colonial society. The Mokolo are, apparently, the alien, aristocratic rule-givers of certain communities of South Sulawesi, whom Alers takes as the model for certain types of "green" rule. The Mokolo are typically a closed caste, filled with a 'Nietzschean consciousness of superiority and disdain for the rest of society, whom they alternately regulate, patronize and exploit. They do not mingle with the rest of society, and live by their own quite separate code, which is not imposed on the rest of the community. Alers describes the Dutch bureaucracy as typically Mokolo (the ultimate of "green-ness"), with race-coloration substituting for aristocratic-hegemonic esprit-de-corps. The 'inner' bourgeois character of the Dutch colonial rule thus assumed an 'external' aristocratic Mokolo character vis-à-vis the brown-skinned populations. Foreign observers of post-revolutionary Javanese administrators in the non-Javanese islands have noted the trend towards Mokolo-ism in their behaviour. 
from the ravages of Westernization, mutuality was quite close. The pamong-pradja, whose whole position rested on adat, naturally tended to find this outlook agreeable; and the "moral" emphasis of Ethical rule, in which concern for what was conceived to be the good of the ruled, echoed older Javanese ideas about the duties of the ruling class. To the classical motto of the prijaji administrator: sepi ing pamrih, ramé ing gawé, mangajuajuning buwăna (be disinterested, work hard, to perfect the world), the ambtenaar of the Ethical school could gladly say Amen. Here Leiden and Jogjakarta met and fully understood one another. The ideal prijaji administrator, as the man who carries out his duty to the state in a gentlemanly manner, with a minimum of (overt) ambition, elegant, polite and honorable, has more than superficial resemblances to the old-fashioned Ambtenaar, the man of eer and hoffelijkheid.

For the pamong-pradja prijaji then, the type of Dutch that was acquired tended in many cases to reinforce, or at least not strongly disturb, traditional attitudes. The inner language of the Dutch civil service classified political phenomena (on the grand scale) in terms not too far from those already familiar to the Javanese civil service; the fact that the two organizations were functionally complementary also helped to ease the process of mutual assimilation, or rather, in the 20 th Century, the slow assimilation of Javanese modes of rule to Dutch methods. On a smaller scale the inner vocabulary of Dutch bureaucratic intrigue and office gossip percolated rapidly through to the Javanese counterpart. The pamong-pradja official would also (rarely) have ruzie met zijn baas (trouble with his boss), complain that some colleague was erg koppig (very obstinate), shake his head that some too outspoken friend had been strafovergeplaatst (transferred to a remote station for punishment), and worry about the herrie (trouble) caused, say, by the unaccountable spread of Sarekat Islam. He might worry about het volk after a bad harvest, and would certainly fuss that his office be kept netjes with everything in orde.

The crucial aspect however of the whole bi-lingualism of the pamong-pradja was that in most cases it provided a means to cope with the real social-political position of this class, both vis-à-vis Dutch superiors and Javanese subordinates. The conservatism of the pamong-pradja as a group, the fact that their interests lay in defending an older and established order, also meant that it was easy to absorb out of the Dutch universe only what was essential to buttress the gaps in the Javanese universe. In this respect Dutch played a fulfilling and adaptive role, with Javanese remaining the dominant "mode" in the official mind. With no mission to fulfil except the maintenance of an existing order, the pamongpradja class was able to make a much more 'stable' adjustment to its own bilingualism, and undergo far less psychological stress in the process, than the nationalist intellectual class Nonetheless, since the great majority of the younger nationalist intelligentsia was intimately related to the pamongpradja, and indeed simply formed one part of the larger prijaji 
class, the experience of the older generation pamongpradja formed a bridge between the purely Javanese experience and that of the nationalist revolution. Rather than simply absorb and adapt Dutch 'partially', to reinforce Javanese traditions, the younger intelligentsia, drawn mainly from the professions, was to build on the alder generation's experience, and advance to the radical absorption of Dutch as a "whole" - including the metropolitan spectrum of Dutch culture - and consequently in the long run to destroy Dutch colonial power from within.

\section{The Nationalist Intelligentsia}

Whereas the pamong-pradja was to the end well-adapted to the maintenance and continuation of Dutch rule, it was very early recognized by colonial conservatives that even the limited Dutchlanguage education provided by the colonial authorities was creating a new class of Indonesians (Javanese in our case), unprecedented in Javanese history and whose very existence presaged the end of Dutch rule. This group of so-called half-intellectuelen, gladakkers, ruziemakers, even sloebers, was contrasted in the Dutch colonial mind with a sentimentalized adel (nobility) and eenvoudige tani's (uncorrupted peasants), who served the regime in a more or less 'mystified' way.

For these intellectuals, without a real function within the structures of the colonial system, but the potential leaders of a post-colonial society, bi-lingualism was not the key to a "modernization" of regional tradition. It opened the way to a critical conception of colonial society as a whole, and a possible vision of a society after the disappearance of the colonial regime itself, be it in the simplest and most abstract terms. It is here that the role of Dutch was of crucial importance: it provided the necessary means of communication between the anti-imperialist and anti-colonial critiques of West European and later Russian Marxism and the potential revolutionary elite in Indonesia. This process is of course a commonplace of colonial studies. What is often insufficiently stressed is the clarity of this revolutionary social-democratic mode of thinking within the mystagogic colonial literature: its coherence, simplicity, organization, and comprehensiveness vis-à-vis the factitious (and real) discontinuities and "complications" of racial division, adat particularity, religious schism, etc., which made any attempt to think in a totalist way about Dutch power so difficult within the framework of the regional languages, even ones as highly organized as Javanese. Just because Dutch power was wider than any "ethniclinguistic" group, and spread deeper than the stratification of traditional society, it could only be responded to within terms wisich it laid down itself. The mode of comprehension was therefore necessarily Dutch; the mode of onslaught and attack was subsequently to be Inconesian (Revolutionary Malay). The spread of Indonesian as a national language was impossible, paradoxically, 
except once Dutch had been developed as the inner language of the intelligentsia: only thus could Indonesian be developed to receive a frame of reference and a formed and coherent Weltanschauung, ready for further diffusion within colonial society.

It can be safely said that whereas openly "conservative" Dutch thinking had virtually no impact whatever on Indonesians (the disguised conservatism of the Ethici of course did have significance in pamongpradja circles), Dutch socialist and communist writing affected virtually the whole of the intelligentsia of the $120 \mathrm{~s}$ and $130 \mathrm{~s}$. For this reason a socialistcommunist vocabulary became the common property of the entire nationalist elite of those years. It is important however to stress that this vocabulary was basically "dual" in that it provided at once a critique of the existing order and a program for its replacement, which though within the West European framework (possibly) inseparable, once outside that environment were quite easily disassociated. Precisely because the critique offered by Marxism was brilliantly apt, and ruthlessly "clear," it was taken over wholeheartedly by all important segments of the elite. The subsequent Marxist program was neither terribly apt nor in the least clear, especially across cultures, and so remains ambiguous to the present day. While the Marxist criticism of colonial society was based on the observed facts of that society, the futures profferred by Marxism were based on very little which had meaning in itself for the literati of Java; and the meaningfulness of Marxism as a practice varied largely according to the real degree of assimilation to Dutch culture and the Dutch language.

All Indonesian intellectuals of the '20s and ' 30 s were posed the problems of cultural and spiritual dualism in their harshest forms. Rare indeed was it to find anyone who could hold the two universes completely separate or in balance. There was a general tendency for the weight of individual's personality to be laid on either the Dutch or the regional-traditional "leg." Those who rested on the Dutch "leg" came to find that dialogue and intercourse with the Dutch enemy was easier than with the provincial and rural Indonesian masses. Many of them lived for at least some years in Holland and in Europe. Many also became active members of the Dutch Left, whether as socialists or communists. On their return, it was common for them to adopt a political strategy of "cadre-forming" among, Dutch-educated younger intellectuals to whom they could talk in the same general language that they had used with their Dutch socialist or communist counterparts. It was no coincidence that the strategy of the HattaSjahrir group in the early thirties was thus devoted to building up an elite circle of Dutch-speaking "radical" intellectuals. Needless to say, neither intellectual ever had any significant mass support. On the other side there were 
intellectuals whose assimilation of Dutch was much more superficial, who had few close relationships with Dutchmen, and who felt more comfortable within the traditionalist milieu than in the "international" socialist-communist intellectual world. For such men the determining experience of life was not the "break-through" into internationalist "modernism." The fact was that for them political action became meaningful and successful not through dialogue with the Dutch, but with their own regional traditionally-minded communities. Whereas intellectuals in the first group were closer to like-minded Dutchmen than unlike-minded Javanese or sundanese, the reverse was the case with the second group. To a large extent, though acting as intermediaries of "outside" ideas down into the traditional world, they never moved effectively or comfortably outside it. For this reason the natural line of political strategy was the mobilization of the masses, within an intellectual universe largely incomprehensible to the Dutch. Precisely because this was their strength, their grip on programmatic Marxism remained extremely weak - indeed the conscious dilemmas of post-revolutionary Indonesia with regard to the organization of her future results largely from this fact.(6)

Nonetheless, the two groups abstracted in this analysis (actually there were no such groups, but a whole range of personalities between the two polar "types") were united by the language of the colonial ruler. Since it was the school language of this whole generation of intellectuals which grew up before the Japanese Occupation, it remained the inner language of elite discourse, especially between nationalists of different ethnic groups. It was the medium for thinking about and absorbing ideas and institutions from the West (including Russia) which promised to liberate and elevate the peoples of Indonesia from the grip of their white masters. It also built up elite cohesion vis-à-vis the Dutch and the indigenous masses. And because, as mentioned previously, Dutch education was largely given to the children of prijaji (even upper level prijaji) families, it was subsequently to appear as a sort of diploma of high status within traditional society. To this day the vague line dividing those who are binnen (in) and those who are buiten (out) in Diakarta politics remains fluency in the colonial language.

In spite of the elite's full or partial mastery of Dutch, the colonial government's educational policies made it clear

(6) One could say that the difference lay between those who basically 'thought' in Dutch and those who, however fluent their Dutch, subconsciously translated as thev went along from the structures of their own regional languages. Later, as we shall see, both translated into Indonesian, Sjahrir from Dutch and Sukarno from Javanese. This is made strikingly clear in Sjahrir's Perdjuangan Kita (November 1945) and Sukarno's Lahirnja Pant jasila (June 1945), neither of which are fully comprehensible without the reader knowing something of the mother-tongues involved. 
that there would be no possibility of using Dutch (as English was used in India) to unite the regional nationalisms into a solid anti-Dutch front. A language had to be found which could be used across the complications of ethnic and status lines to fulfil the unifying function at the mass level which Dutch performed among the elite. The language would thus, since it was called into being by the nationalist struggle, represent in itself the pure spirit of resistance to the domineering monopoly of Dutch as the bridge to "modernity." It would in itself declare the cultural defeat of centuries of Dutch rule.

As is very well known, pasar (market) Malay had long been the lingua franca of the archipelago, and this became the basis of an essentially political language, Indonesian (Revolutionary Malay). It was a language simple and flexible enough to be rapidly developed into a modern political language, analogous but, as it were, verso to Dutch, without strong traditional traits (mainly $\overline{\text { syntax }}$ and honorofics) exercising their own contradictory influences. This was all the more possible because Malay as an "inter-ethnic" language, or lingua franca, had ipso facto an almost statusless character, like Esperanto, and was tied to no particular regional social structure. It had thus a free, almost "democratic" character from the outset, which had its own appeal to an intellectual class, which at one level (the desire to be on equal terms with the colonial elite) aspired to egalitarian norms. (7) It has often been said (mainly by the Javanese of a later day) that the adoption of Indonesian as the national language was a magnanimous concession on the part of the Javanese nearmajority. It seems more likely however that, since even for the more traditionally oriented intellectuals the drive for modernity was at that time still partly seen in terms of breaking out of "Javanism" and the hierarchical modes of Javanese social intercourse, the simple modalities of Indonesian had their own ideological appeal. The language moreover offered the possibility of relating socially in an essentially Dutch manner, but without the mediation of the Dutch language. The very awkwardness and unfamiliarity of the new language reflected the sense of creativity and exploration of a "socialist" and would-be egalitarian experience. Being at once "national" and modern it was able to satisfv, at least in part, both ideological requirements and the need for a sense of cultural identity within a common enterprise.

(7) The inter-ethnic character of the language made it all the more successful as an unifier, since it was not tied in with the interests of any maior ethnic-linguistic group in the struggle for inter-regional ascendancy. 
The Adventures of a New Language

The major public function of Indonesian and its key political significance has lain in its role as national unifier. Though it began to play this part in the 1920's it was not until the Japanese Occupation that it formally became the National Language, to be taught in schools and used in offices as a matter of official policy. And during the Revolution it was above all the language of resistance to the returning Dutch and the language of hope for the future. The Revolution also started the process of filling Indonesian with the emotionally resonant words which give any language its cultural identity and aura, and which seem to express its speakers' most intimate experience. The key words Rakjat (People), Merdeka (Freedom), perdjuangan (struggle), gerakan (movement), kebangsaan (nationality), kedaulatan (sovereigntv), semangat (dynamic spirit), and above all Revolusi: all stem from the seedtime of the Republic, the time of its most violently anguished awareness of itself as the expression of a hopeful new enterprise and solidarity. Virtualiy all the emotive words in Indonesian are centred round the struggle and violence of the physical revolution and almost all have highly politicalheroic connotations. They live and vibrate because they are part of the historical memory of a still surviving generation, and were "coined" within the most important experience of modern Indonesian Iife. The contrast with Javanese, where the emotive words, sonorous and onomatopoeic, have grown in depth and resonance over generations, on a withdrawn aesthetic and religious level, is striking.

Aside from the key words born of the Revolution and the struggle that preceded it, Indonesian is a language without extensive historical memories and connotations to it. It looks to the future, and as such it is par excellence the language of youth and rebellion. For the majority of literary artists too, who feel the oppressiveness of the Dutch and Javanese literary traditions, Indonesian offers an attractive medium of expression. Its very flatness and simplicity allow writers to feel that they can create and mould it in their own image and according to their own aspirations. But though for the chosen few Indonesian's lack of "given-ness" creates a sense of liberation, both literary and political, there has always been an underlying cultural risk involved. Especially since the Revolution the language's lack of cultural resonances, of a solid tradition, has led to considerable transformation of the language, as we shall see below.

Furthermore, precisely because Indonesian represented in essence a "project", an aspiration to unity and equality, a generous wager on the future - in the face of some increasingly intractable social facts - the language has gradually developed a "formal" character which has till now scarcely been commented upon. Modern Indonesian has something curiously impersonal and neuter about it, which sets up psychological 
distances between its speakers. This is not because of any social stratification "built into" the language, but, paradoxically, because of its democratic-egalitarian character in a society still so largely and traditionally status-oriented in its deepest thinking. (By contrast, the extremely stratified modalities of Javanese create a strong sense of communal identity!) The vitality of Indonesian depending less on its historical antecedents than its symbolic character as an expression of the anti-colonial project (at once the unification of the whole former Dutch colonial empire into a harmonious nation, the democratization of the national community and the growth of a free spirit of fraternity), the post-revolutionary fate of this project has had decisive effects on the language. Forming a new and thin topsoil to the cultures of Indonesia, it has proved only too liable to suffer erosion once the winds of change began to blow.

The development of the language in the post-revolutionary period shows clear signs that this has been happening. It is not so much that the language acquires a new vocabulary as such (though this indeed is also occurring) but that the older words acquire a 'satanic' reversed meaning, expressing almost geologically the transitions from the hopeful years of the revolution to the harsher, grimmer years that have followed. The most celebrated example of this has been the fate of the word bung, which has suffered a kind of amoebic fission. During the Revolution the word bung (brother) expressed the real fraternity of the national struggle, and was used freely by all active participants in that struggle. Todav, with the exception of a few national figures like Sukarno, Hatta and Sutomo, (and in their case bung is spelt Bung), virtually no one of importance is referred to in this way (outside small nostalgic leftist cliques). While the Bung half of bung has stayed high and honorific, the lower bung half has slipped lower and lower, and is now generallv a peremptory, disdainful means of summoning an oplet-driver, waiter, doorman or street cigarette-seller. Another example is the word aksi, which in the heyday of Tan Malaka's Massa Aksi meant Action, Revolutionary Mass Action, and even now crops up in the names of such organizations as KAMI (Kesatuan Aksi Mahasiswa Indonesia - Indonesian Students' Action Union). More often today, however, it is the satanic reversed meaning of aksi which is widespread, in the sense of a "show" (pretentious, fake, artificial). Such further examples could readily be provided. The point is not that these words are used cynically, but precisely that they are not. People use Bung and bung, Aksi and aksi, quite unselfconsciously, in their disassociated meanings.

This fission within some of the most important emotive words of the Indonesian language reflects both sociological and metaphysical characteristics of post-revolutionary Indonesia. It represents the re-stratification of contemporary Indonesian 
society, and the metaphysical determination to maintain the aspirations and idealism of Indonesian in a changing social context by a traditional process of (so to speak) "dualization" and disassociation.

This is revealed all the more clearly when one takes into account that even today, twenty years after the Revolution, Indonesian is by no means the everyday language of more than a tiny segment of the population. One can say with some confidence that in fact in only two cities in all Indonesia is Indonesian the normal medium of communication outside official channels. The great provincial capitals, Makassar, Padang, Palembang, Bandung, Surabaja, Solo and Semarang, all speak their own regional languages - be it Makassarese, Minangkabau, Sundanese or Javanese. Only in Medan and Djakarta is Indonesian the real urban language. Even here, Medanese is really, for historical reasons, more "Malay" than Indonesian, and has much of the character of a provincial dialect.

It is only in the melting pot of Djakarta that Indonesian has developed and shown its creativity in the post-revolutionary years. This has partly been a product of an immense influx of fortune-seekers, especially from Java, but also from all the other islands, into a Capital where so much power and wealth is concentrated. It also reveals the peculiar personality of Djakarta, its sense of solidarity vis-à-vis the daerah and the rapid, brutal, commercial, power-oriented and humorous character of metropolitan life. The main aspect of Djakarta's influence on Indonesian has been the growing incorporation of the so-called bahasa Djakarta, or at least major parts of it, into the national language.

Bahasa Djakarta or bahasa Betawi has long been in existence, developed over decades by Balinese, Sundanese, Buginese, Javanese and Chinese settlers there. It is a rough, urban, lower-class speech, totally without "high" moral or aspirative traits. It is virtually impossible to be "serious" or even "pompous" in bahasa Djakarta, so brutally earthy, direct and humorous is the language. By an unexpected turn of history however, this Iumpen-language has increasingly become the "in" language of the Djakarta elite, especially in the later fifties and sixties. Particularly for the younger generation of politicians, officials and students, bahasa Djakarta, in slightly refined form, has become a normal mode of social intercourse. Its popularity clearly derives from its intimate, jazzy, cynical character, which forms a satisfying counter-point to the formal, official Indonesian of public communication. It provides an "id" for Indonesian's "ego." It expresses the danger, excitement, humour and coarseness of the new Djakarta as no other language could do. Its harsh, acrid onomatopoeia parallels the flavour of ngoko in Javanese, while bahasa Indonesia grows more and more into a form of krama. 
The most interesting external manifestation of this is the metropolitan newspaper, which, for our Durposes, can be divided into two quite clearly separable portions. First, the portion in bahasa Indonesia, which covers all news items, all features, and all editorials (about $95 \%$ of the newsprint). Second, the portion in bahasa Djakarta, which covers only the podjok. Though the podjok rarely run more than half a column, they are normally the first thing in the paper that the Djakarta reader turns to. The essence of the podjok is biting, anonymous comment on the latest news or the general political or economic situation. often they will indirectly refer to events which are "open secrets", though the censorship will not permit them to be mentioned elsewhere. The podjok frequently take the form of dialogues between two (supposed) proletarians or petty traders: Bang Dul, Pak Otong, etc., etc. The art of podjok-writing is one of allusion, innuendo, sarcasm, mock surprise, poker-faced apophthegms, and dot-dot-dot, almost impossible to convey in another language. But as a simple examole, a podjok may quote a senior Minister or Army officer making an uplifting speech in Indonesian about the need to live simply, avoid corruption and work hard. On a separate line comes the rejoinder: Bener deh! (Quite right). Evidently a simole agreement with what the great man has said. But the metropolitan reader immediately notes that the podjok-writer has used the Djakarta bener not the Indonesian benar (bener has strong come-off-it connotations), and has added the untranslateable but salty particle deh (something like'indeed') which is typically Djakarta and pithily expresses sarcasm, ridicule and disbelief. In just two words then, the podjok formally praises the Minister or officer, while at the same time implying that he is hypocritical, lazy, corrupt and pompous. Or again the podjok may simply say: Hasilnjé adé djuga. Ikan gedé ketangkad. Alhamdulillah! ( It finally worked. They got a big fish. Praise be!). From the sarcastic "Praise be!" and the Djakarta suffixes, the reader will immediately know or guess that an important political figure has been arrested for corruption, though the case itself, and even the arrest, may never be made public.

The contrast between the Indonesian and Djakartan sections of the newspapers is complete and immediate. The Indonesian parts are high-minded, serious, and moralizing, usually sermons by the President, Generals, Ministers or editors. They are doubtless very improving, but also official, aspirative, ideological, patronizing and authoritarian. All are directed down the social-political hierarchy from the Great to the Small, from the pemimpin (leader) or tokoh (bigshot) to the rakjat (peodle), wong tilik (the little man) or the massa (the masses). The Djakarta parts are snide, corrosive, democratic, humorous and above-all intimate. The empty distances of Indonesian are immediately scaled down to the knowing intimacy of Djakarta. As the Djakarta-speakers put it, it conveys a pervasive atmosphere of "TST" (tahu sama tahu - we understand each other).

It is not just the inflections which are in striking contrast 
it is also the vocabulary itself. The editorials centre round words like: imperialisme, pembangunan (upbuilding), kemadjuan (progress), amanat penderitaan rakjat (message of the people's sufferings), kontra-revolusioner (counter-revolutionary) and perdjuangan (struggle). The podjok speak in terms of: masuk kantong (filling one's pockets), sepak ke atas (kick upstairs), njatut (to chisel), djatuh ke kasur (fall on a mattress - i.e., be removed from office but be given a fat sinecure as consolation prize), main kaju (playing it rough and dirty) and ngakunjé (so he claims). The editorial may speak of demokratis (democratic) - the podjok echoes it as dia mau gratis (he wants it for nothing).

The question arises therefore as to what is really taking place with this emergence of Diakarta as a key element in the metropolitan language of politics. It is clearly unprecedented in Indonesian history in its terminology, which derives from the post-independence situation, where Indonesians control their own government, and rulers and ruled (higher-level ruled) engage in some form of intimate dialogue. There is the temptation to regard Djakarta as the "real" language, the "in" language, while Indonesian is merely for show, propaganda or self-aggrandizement. The cynical wit of the podjok and of the metropolitan gossip network are easy enough to take as the "reality" until one recognizes that Djakarta is still the language of one city, with virtually no roots outside, and that for the great mass of Indonesians at all involved in politics, Indonesian retains its hold as the symbol and promise of the future, and has a reality which transcends the hopes and fears of the present elite.

We are back with the problem of the mask. Public mask, and private face, which is real? Why is the mask so important? What is the private face without the public mask? Does the mask mislead, attract, symbolize or possess?

\section{Javanese Modalities and the Present Cultural Crisis}

The deepening crisis which has preoccupied all politicallyminded Indonesians since at least as far back as 1956 (that is now for almost a decade), while many-faceted, centres psychologically and culturally on the petering out of the earlier revolutionary impulse within the revolutionary elite. Sociologically it is manifested in the growing stratification of Indonesian society, the increasing isolation of the elite from the masses, and the development of parasitic bureaucratic structures in all fields of social activity. Politically the slow narrowing of the government's political base, the uncreative conservatism of its policies, and the ever more frantic effort to protect its own vested interests reflects the same condition. The economic situation is in no way more promising. The impact of these changes on the language of Indonesian 
politics and Indonesian nationalism has been of great importance. Part of what has been happening has been an inevitable process of Javanization of Indonesian, both in terms of vocabulary and in terms of modalities. Part of it has been the drying up Indonesian (Revolutionary Malay) as a well-spring for renewed social creativity. Very probably the most important development has been this last: the slowdown of the revolutionary essor at the centre of Indonesian politics. But the two are intertwined, the relative ascendancy of Indonesian and Javanese is in itself an indicator of the internal psychological and metaphysical state of the nation and of the general road down which the Indonesian elite has been heading. Given the growing paralysis of the revolutionary impulse, "revolutionary" Indonesian has been increasingly felt as "out of touch," almost dysfunctional to communication within the emerging system. The only mode for grappling linguistically with this change has been to rely more heavily on an older, more elaborate, and possibly more enduring tradition. The problem is not, as has been so often vulgarly expressed, the cultural imperialism of the Javanese, but the impending defeat of Indonesian (for the nonce at least), not as a language, but as an autonomous modality of thought. The Indonesia-thinkers have been $f e w$ and far between, and have not been able to impose this mode of being as such on the political public.

The Javanization of Indonesian has a number of facets to it, all of which are closely connected to the objective social and political situation.

1. The kramanization of public Indonesian. As the "reality" of revolutionary Indonesian has increasingly been undercut by events, official Indonesian has tended to become a language of political politeness, in which any educated modern prijaji should be fluent, and which in effect separates him from the rakjat jang bodoh. (8) This "etiquette" helps to disassociate the prijaji in at least part of his spirit from the rawer crudities, and to maintain contact with the more ideal, halus aspects of contemporary politics. The acquisition of the vocabulary of Indonesia krámá in itself involves a form of inwijding, or initiation into a higher level of political sophistication and civilization. It is a kind of spiritual self-discipline in itself to become fully aware of the nuances and ambiguities of the public language.

(8) The newcomer is often struck by the unselfconsciousness with which the prijaji (even 'leftist' prijaji) refer to the 'masses' as bodoh, since this word is usually translated as 'stupid.' It seems intolerable snobbery, and indeed often is. But when one hears the same man talking about the people as masih bodoh (still stupid), the difficulty becomes clear. For the West stupidity is determined, and is a trait of a "fixed" personality. We never talk of people being 'still stupid.' For the Javanese 'stupidity' is the reverse of being 'educated' or 'awakened.' It is therefore a failing which can (in theory) always be remedied. 
Just as kråma itself originally represented a literaryreligious glorifying and archaizing of the basic ngoko vocabulary, one finds that the kramanization of bahasa Indonesia naturally turns in the same direction, at once both by glorification and archaism, which, as always, is intended to link and identify the present with the heroic past. The archaisms and honorifics tend to come from Javanese and Old Javanese, since both for sonority and for glorious historical resonances these two languages form the richest treasury. Thus Pantjasila, Indonesia's 'modern' political ideology, was originally a set of Buddhist principles, mentioned in the earliest known Javanese epic, the Nagarakrtagama. The modern krama name for the Mobile Brigade of the Police, Bhayangkari, is the same as that used in Old Javanese for ipalace Guard. The Sapta Marga, ideological charter of the Indonesian Army, is again 0ld Javanese for the Seven Paths. There are dozens of these archaisms now current under late Guided Democracy: Tri Ubaja Sakti, Pantjatunggal, Pantjawardhana, Mandala, Satya Lentjana, Pramuka, etc. etc. Many of them are true krama words in that there are 'ordinary' or ngoko everyday equivalents: (e.g. Mobrig for Bhayangkari). All of them tend to be used most on occasions of high ceremonial importance, and to be applied to objects and institutions of the highest political prestige. While almost none of these words are understood fully in their original sense, the fact that they are of Sanskritic or old Javanese origin is well understood, and therefore the modern institutions are seen as inheriting the prestige and majesty of the originals.

2. The new ngoko. It has already been suggested above that bahasa Djakarta has at least partially been absorbed into political Indonesian to perform the role of ngoko, as Revolutionary Malay has gradually moved up to kråma status. This is undoubtedly the case, and shows how Javanese modalities have penetrated Indonesian even more than Javanese as a language. But it is also true that there has been a steady influx of ngoko Javanese words into Indonesian at all levels (almost none from contemporary Javanese kramá). This partly reflects the actual and growing power of the Javanese, and especially Sukarno, at the centre of Indonesian politics since 1956. Since Sukarno and the P.K.I. (also heavily Javanese) have been the only two consciously creative or innovative forces in developing the modern language of Indonesian politics, this verbal Javanization (which is now even quite fashionable) shows its ancestry rather clearly. The most wellknown Javanese imports, words like: ganjang (eat up), krumus (chew up), gontok-gontokan (brawling), nggrogoti (undermine by gnawing), bobrok (hopelessly rotten), plintat-plintut (halfhearted), berkiprah (strut in victory), not only have the typical Javanese sensual immediacy (by onomatopoeia), but are almost invariably words implying danger, disaster and physical violence. This in turn is unmistakably a sign of the deepening social conflicts and tensions of the past decade, as the economic and 
social plight of the Javanese has become markedly worse, and as hatreds have been turned inward on the society itself rather than on the outside world.

3. The neutralization or capture of revolutionary symbols. This can be described as the process of assimilating those symbols to an unrevolutionary, even anti-revolutionary traditionalism. It is done in two ways:

(a) by burying words of great symbolic power like revolusi, sosialisme, demokrasi, which have real historic roots, within hermetic acronyms like Resopim, Djarek, Usdek. These combination-words are not 'functional' in the sense that sovkhoz or Nep once were - convenient abbreviations for practical policies and concrete institutions. They are what one could half-paradoxically call synthetic syntheses of ideas which may have neither concrete reality or communality, but which by verbal manipulation may be thought to acquire a life of their own. Djalan Revolusi Kita (The Course of Our Revolution) is still an attempt to use words syntactically to convey an idea or an appeal. Djarek. however is not a word at all, but quite literally a thing, into which the ingredient 'revolusi' has been stirred. It has become a mantra in which the overt meaning is of no importance. In Western eyes it has been reduced to one of the Charms (Azimat) of the Revolution. Looked at somewhat differently, it represents a transformation of alien symbols and messages, precisely parallel to what we have observed happening to Arabic and Islam in older times. Like Arabic the external language of revolutionary socialism has been taken over and given an esoteric sense, scarcely connected at all to its overt sense. The esoteric sense is to be grasped largely by intuition. The acquisition by rote of the newer acronyms thus forms an exact parallel to the learning of the incomprehensible ajat of the Koran in the pesantrèn; it is part of a spiritual training. We can attribute quite similar functions to Usdek or Takari and the formula Bismillahirochanirochim. (9)

(b) by "reifying" action and process into essence and quality. Sukarno has constantly been accused by his Western judges of 'betraying' socialism, democracy and revolution. What many have failed to realize is that these words are no longer translations of sosialisme, demokrasi and revolusi, which have now independent, free-floating meanings of their own. When Lieutenant-General Soeharto talks quite seriously of "the

(9) Thus the use of these mantra should be seen neither as "magic", as certain Gallic commentators have supposed, nor as hypocritical sloganizing, as too many of our economic missionaries have insisted, but as something like prayer, in the sense used by Jim Siegel in the first article of this issue. 
hierarchy of the revolution being disturbed," or refers (not in the least cynically) to the Communists as "counter-revolutionary" and "liberal," it is clear that these words have an esoteric sense all their own. Revolution is no longer a social process but a state of mind, or a combat record. One may "be" revolutionary (ex officio, by having participated in the nationalist struggle) or "become" revolutionary (by "mental retooling" as General Nasution puts it so elegantly - i.e. by having one's mental wavelength changed) but one does not "act" revolutionary. What is socially approved is a state of mind, not a series of deeds. Similarly, the official can simultaneously loudly applaud the slogan-phrase gotong-rojong (mutual help and cooperation) and denounce the slogan-phrase sama rata sama rasa (all equal in status, all feeling equal). This is because sama rata sama rasa (popular in leftist circles) still retains its original meaning, while gotong-rojong has been reified into the-word-for-thepresent-mode-of-government. Ipso facto then, gotong-rojong is desirable and practised.

A similar process is at work in the transformation of words like demokrasi and sosialisme. We fall into a nominalist heresy when we identify socialism and democracy as things Which Are they are only what we make them. If we were to imagine the adventures of the Indonesian idea of musjawarah or the Javanese idea of gotong-rojong, once taken over by the American educational establishment and inculcated into the younger generation of Americans, we can come to a much more serious conception of the whole trend to absorb and transform the Western concepts of modern politics within Indonesian-Javanese mental structures. In any such cross-cultural confrontation, the inevitable thrust is to "appropriate" the foreign concept and try to anchor it safely to given or traditional ways of thinking and modes of behaviour. Depending on the conceptions of the elite and its determination, either the imported ideas and modalities or the traditional ones assume general ascendancy: in most large and non-Communist societies it is almost invariable that, at least in the short run, the traditional modalities tend to prevail.

4. Javanese images of politics. It has been frequently argued that the Javanese sense of history is cyclical and not linear, and my own feeling is that in general this is true. At least where we tend to look for parallels, many Javanese look for reiterations or reflections. The subject is an exceedingly complicated one, which can not be dealt with satisfactorily in this essay; nevertheless it is worth considering what for example is the fate of the idea of Revolution within a cyclical (but is not Revolution basically a cyclical image?) intuition of history: Does it not really end up in Dr. Subandrio's "revolution is continuity!?"(10) In the classical cycles of Javanese historiography, the golden age of the distant past gradually

(10) As cited from Lance Castles' article in this issue. 
disintegrates into successively lower and more miserable eras, culminating in the era of disaster, the Kaliyuga or Djaman Edan (The Age of Madness) in which all values are transvalued, all social institutions turned upside down, and society is broken apart. But the wheel of time continues to revolve, and out of the darkness of the Djaman Edan, a new golden age begins again under a new Ratu AdiI (Just King). Here is "revolution is continuity" with a vengeance! The metaphors of cycle and revolution come together without too great a shock within this larger perspective. Sukarno's Sosialisme à la Indonesia is much closer in every way to the Djaman Mas (Golden Age) than it is to Marx's classless society. It is a restoration above all: the old order re-emerging in technical, modern dress; the golden age at a much higher level of average income per capita, but with the older verities and structures scarcely altered.

The Javanese image of the components of their own society is another case in point. The dominant division is undoubtedly between the aliran (stromingen, streams), and not between classes or even political persuasions. The aliran are basically discontinuous mental universes and ways of life, which flow across class lines, and can not be easily subsumed under the rubric ideology. They lie under the political parties but are not of them. The NU, PSII, Perti, can all be seen as part of the Islamic or santri aliran, for example, but that aliran includes quite non-political peasants, teachers, traders, etc. There is (still) a communist aliran (part of a larger abangan aliran) and a prijaji-nationalist aliran. The division of the community by aliran is a peculiarly Javanese 'analysis' of society, which is increasingly imposed upon Indonesia's own internal view of her politics. Yet these aliran are (and this in spite of the present brutal massacres perpetrated against the communists) "givens" in the Javanese political landscape. There is no real expectation (pace General Nasution) that they are anything but permanent aspects of Javanese society, sometimes up, sometimes down, but part of an ongoing order.

Finally there is the image of the mask and the puppet, which we have alluded to at intervals throughout this discussion. The ostensible vocabulary of Indonesian political language has increasingly been dominated in recent years with words which explicitly or implicitly evoke these images: dalang, mendalangi, wajangnja, lakon, gara-gara, prang tanding, djedjer, Bratajuda, Durna, are all political words drawn from the language and universe of the shadow-play. Kedok (mask), as used in phrases like terbuka kedoknja, dengan kedok..., refer to the images of the mask, both in the topeng mask-dance and in the dualistic structures of Javanese social relationships. These are all terms which have a special resonance for the Javanese, indeed the words themselves are almost all Javanese in origin. So deeply imbedded are these images in the Javanese mind that conceptions of the "game of politics" are invariably coloured by them. It is very hard for 
Javanese, and increasingly for all metropolitan Indonesians, to believe in any form of political spontaneity - in the accidental or fortuitous. Something is always going on "behind the screen" where unseen dalang are at work. The public "appearance" of the great is always regarded, less with cynicism than with the faith that to some extent at least it is a mask. The obsession with intrigue, with the sandiwara (stageplay) of politics, even with the aesthetic side of political behaviour (the art of playing politics) are characteristic of a view of politics in which virtù (adeptness) in sudden transformations and role reversals is an accepted political value. Politics as elaborate and magnificent drama, rather than as a process for the attainment of specific ends and the satisfaction of concrete interests - this is a viewpoint which at least in its symbolism derives from the central role of traditional religious drama (wajang) in the Javanese experience.(11)

But here perhaps we can see also that Indonesian (and perhaps 'modernity') is having its revenge. For though the image of the mask is as powerful as ever, its ambiguity appears to be declining. This is, historically, the result of the buffeting which the older traditional conceptions of opposites as complementarities and as expressions of an underlying continuum are receiving in contemporary Indonesian conditions. There is a growing uncertainty about the relationship between the seen and the unseen, the real and the Real. The idea of the mask thus increasingly becomes purely and simply the idea of a factitious disguise for a hidden purpose, worn to deceive or to conceal a truth. The growing popularity of words to describe "hypocrisy": munafik, gadungan, sok, palsu, plintat-plintut, bermukadua is thus significant. All these words imply a sinfle Real reality, which is being betrayed by hypocritical and two-faced elements. Thus the language and imagery of Javanese tradition here survive, but within an Indonesian-Western modality which has largely stripped it of its metaphysical richness.

To conclude then, it appears that the languages of Indonesian politics are approaching a fusing point, which will be all the more rapidly attained when the old Dutch-speaking elite dies out. The radical gaps between Javanese and its traditions and revolutionary Indonesian and its aspirations seems destined to disappear, by assimilation and the changing character of the contemporary Indonesian experience. The structural Javanization of Indonesian and the imposition of Javanese modalities does not alter the fact

(11) For further discussion of the pictures of politics developed through a wajang education, see B. R. Anderson, Mythology and and the Tolerance of the Javanese, Cornell Modern Indonesia Project, Monograph Series, 1965. 
that the national language remains Indonesian, and that the aspirations contained in the Indonesian project are now permanent within Indonesian society. The whole process is obscure, complex and immensely significant: for it symbolizes and expresses the conquest of modernism via a new language which at the same time is becoming anchored in a traditional conception of the world, and a deep-rooted vision of the nature of being.

Ben Anderson

February, 1966 